\begin{tabular}{|l|l|l||}
\hline \multicolumn{2}{|c|}{ PublisherInfo } \\
\hline \hline PublisherName & $:$ & BioMed Central \\
\hline \hline PublisherLocation & $:$ & London \\
\hline \hline PublisherImprintName & $:$ & BioMed Central \\
\hline \hline
\end{tabular}

\title{
Epigenetics lives on in clones
}

\begin{tabular}{|l|l|l||}
\hline \multicolumn{2}{|c|}{ ArticleInfo } \\
\hline \hline ArticleID & $:$ & 5056 \\
\hline \hline ArticleDOI & $:$ & $10.1186 /$ gb-spotlight-20050204-01 \\
\hline \hline ArticleCitationID & $:$ & spotlight-20050204-01 \\
\hline \hline ArticleSequenceNumber & $:$ & 32 \\
\hline \hline ArticleCategory & $:$ & Research news \\
\hline ArticleFirstPage & $:$ & 1 \\
\hline \hline ArticleLastPage & $:$ & 3 \\
\hline \hline & & RegistrationDate : 2005-2-4 \\
\hline ArticleHistory & $:$ & OnlineDate \\
\hline \hline ArticleCopyright & $:$ & BioMed Central Ltd2005-2-4 \\
\hline \hline ArticleGrants & $:$ & \\
\hline \hline ArticleContext & $:$ & 130596611 \\
\hline \hline
\end{tabular}




\section{Melissa Phillips}

Email: mlphilli@u.washington.edu

A cloned Xenopus embryo overexpressed genes that were being actively transcribed in its parent cell at the time the nucleus was transferred, according to a study published in this week's PNAS. This suggests that the embryo "remembers" what type of cell its nucleus came from, according to study coauthor John Gurdon. He and Ray K. Ng of the University of Cambridge report that genes specific to the cell type of a transferred nucleus are turned on in the wrong tissues of some cloned embryos at early stages of development.

"The idea that active gene transcription can be stable through pretty dramatic cell changes is not new," Paul Wade of the National Institute of Environmental Health Sciences told The Scientist. "What's new is that it survives nuclear transfer."

When a somatic nucleus is transferred to an oocyte, factors in the cytoplasm induce an erasure of the differentiated cell program in favor of an embryonic transcriptional program. But the process is not perfect; previous studies have shown that some genes that are silenced in differentiated cells fail to turn on during reprogramming. $\mathrm{Ng}$ and Gurdon wanted to see if some genes may likewise fail to turn off.

The authors transplanted nuclei from the Xenopus embryo neuroectoderm and endoderm into oocytes that had been enucleated by UV radiation. They dissected the developing embryos into two sections: the animal region, which develops into neuroectoderm, and the vegetal region, which will become endoderm.

In a normally developing embryo, the pan-neural marker Sox 2 is highly expressed in the animal region, but found only at background levels in the vegetal region. In embryos cloned from neuroectoderm nuclei, the authors found that 17 of 21 samples overexpressed Sox 2 significantly in the vegetal region; only four of 18 samples showed abnormally high Sox2 expression in the animal region.

They found the converse effect in embryos derived from endoderm. $E d d$, an endoderm marker gene, is usually expressed highly in vegetal regions but not in animal. In the nuclear transplants, nine of 20 embryos expressed edd more than twice background levels in the animal region, while vegetal expression was almost entirely normal.

"The continued expression of somatic cell genes" is not surprising, according to Keith Latham of Temple University. Nonviable clones presumably fail both to turn off the adult program completely and to turn on the embryonic program completely, Latham said.

$\mathrm{Ng}$ and Gurdon also found that $e d d$ transcription begins early in most animal regions (eight of 10) and some vegetal regions (five of 10) of endoderm-derived embryos. They detected edd transcripts two cell cycles before transcription normally begins in Xenopus, Gurdon said.

Since transcription normally begins in Xenopus after 12 mitoses, the overexpression of cell type-specific genes means that the nucleus is "maintaining an active state at a locus in the face of inactive transcription for 8 to 10 cell cycles, and that is pretty remarkable," said Wade, who was not involved in the study. 
Although they can't be sure of the molecular mechanism of their findings, $\mathrm{Ng}$ and Gurdon speculate that active transcription information could be inherited through histone modifications.

"There's no known mechanism for replication of a modified histone," Gurdon said, "but it seems to be the only plausible explanation."

One of the most striking findings in the paper is the variability of reprogramming efficiency, according to Wade. While many embryos overexpressed genes specific to the transferred nucleus, some embryos seemed to reprogram perfectly.

"This may be an important component of the variability that one sees in the outcome of nuclear transfer experiments themselves," Wade told The Scientist. "I think it's potentially quite important in the variability of the cloning process."

"The fact that [reprogramming] is not perfect isn't too surprising," Gurdon said. "In a way, it's amazing that it works at all."

\section{References}

1. R. Ng, J.B. Gurdon, "Epigenetic memory of active gene transcription is inherited through somatic cell nuclear transfer," PNAS, January 31, 2005., [http://www.pnas.org]

2. The Gurdon Group, [http://www.gurdon.cam.ac.uk/groups/gurdon.html]

3. A. Bortvin et al., "Incomplete reactivation of Oct4-related genes in mouse embryos cloned from somatic nuclei," Development, 130:1673-80, April 2003.

4. Keith E. Latham, [http://www.temple.edu/biochemistry_medical/Dr.KLatham.html] 